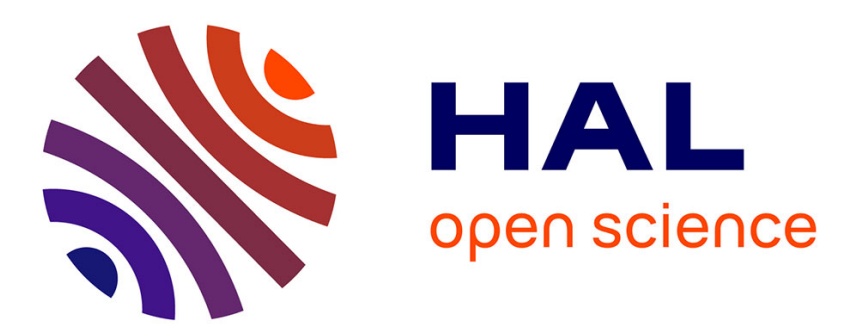

\title{
Proteomic profiling reveals that Th2-inducing dendritic cells stimulated with helminth antigens have a 'limited maturation' phenotype
}

Stéphanie Ferret-Bernard, Rachel Sally Curwen, Adrian Paul Mountford

\section{- To cite this version:}

Stéphanie Ferret-Bernard, Rachel Sally Curwen, Adrian Paul Mountford. Proteomic profiling reveals that Th2-inducing dendritic cells stimulated with helminth antigens have a 'limited maturation' phenotype. Proteomics, 2008, 8 (5), pp.980-993. 10.1002/pmic.200700538 . hal-01369364

\section{HAL Id: hal-01369364 \\ https://hal.science/hal-01369364}

Submitted on 29 May 2020

HAL is a multi-disciplinary open access archive for the deposit and dissemination of scientific research documents, whether they are published or not. The documents may come from teaching and research institutions in France or abroad, or from public or private research centers.
L'archive ouverte pluridisciplinaire HAL, est destinée au dépôt et à la diffusion de documents scientifiques de niveau recherche, publiés ou non, émanant des établissements d'enseignement et de recherche français ou étrangers, des laboratoires publics ou privés. 


\title{
Proteomic profiling reveals that Th2-inducing dendritic cells stimulated with helminth antigens have a 'limited maturation' phenotype
}

\author{
Stéphanie Ferret-Bernard, Rachel Sally Curwen and Adrian Paul Mountford \\ Department of Biology (Area 5), University of York, York, UK
}

Dendritic cells (DCs) are important in the initiation of primary immune responses against pathogens. To aid understanding of how DCs guide T helper (Th)2-type responses, we employed 2-DE in association with MS/MS to identify proteins which characterise pro-Th2 DCs (matured with zero-to-three hours released proteins (0-3hRP), released by Schistosoma mansoni cercariae) versus pro-Th1 DCs (matured with lipopolysaccharide, LPS) and immature DCs. Software analysis of average 2-DE gels (three replicates per DC type) showed many similarities in the pattern of spots between the three groups of DCs but also marked changes. The major and significant changes in protein expression mainly affected cytoskeletal proteins. Other differences included chaperone proteins and enzymes involved in protein folding, S100 calcium-binding proteins, peroxiredoxin 1 , superoxide dismutase 1 , several annexins and arginase 1 . Our study demonstrates that pro-Th2 DCs matured with 0-3hRP exhibit a proteome that is intermediate between that of immature DCs and pro-Th1 DCs. Finally, the differential regulation of protein spots identified by MALDI-MS/MS as having cytoskeletal and morphological functions was confirmed by contrast, confocal and scanning electron microscopy examination of DCs. Together, our results support the view that Th2 differentiation results from a 'limited maturation' of DCs.

Received: June 6, 2007

Revised: October 3, 2007

Accepted: November 15, 2007

\section{Keywords:}

Cytoskeleton / Dendritic cell / Innate immune cell / Parasitic helminth / Th2 lymphocyte

\section{Introduction}

Dendritic cells (DCs) are critical in the development of immunity against pathogenic organisms $[1,2]$. In the periphery, they exist in an immature state but are highly antigen-receptive, acting as sentinels in the recognition of

Correspondence: Dr. Adrian P. Mountford, Department of Biology (Area 5), University of York, P.O. Box 373, York YO10 5YW, UK

E-mail: apm10@york.ac.uk

Fax: +44-1904-328505

Abbreviations: 0-3hRP, zero-to-three hours released proteins; BM, bone marrow; CDS, Celera Discovery System ${ }^{\mathrm{TM}}$; DC, dendritic cell; DIC, differential interference contrast; LPS, lipopolysaccharide; NCBI, National Centre for Biotechnology Information; SEM, scanning electron microscopy; Th, T helper; TLR, toll-like receptor pathogen-associated molecular patterns (PAMPs) [3]. It is widely accepted that DCs can interpret different pathogeninherent signals and play a pivotal role in polarising either $\mathrm{T}$ helper (Th) 1 or Th2 associated acquired immune responses which lead eventually to protection or pathology [1]. While certain pathogens (bacteria, viruses or protozoa) drive strong Th1-type responses [4], it is still not clear what mechanisms are required for DCs to generate Th2-type responses.

Molecules from helminths are some of the most potent inducers of Th2 type responses [5-10]. DCs pulsed with a soluble preparation of schistosome eggs (soluble egg antigen, SEA) stimulate Th2-polarised immunity, while showing a 'modified' immature phenotype [5, 10]. Recently, we characterised the proteome of a similar preparation (termed 0 $3 \mathrm{hRP}$ ) released by schistosome larvae within the first $3 \mathrm{~h}$ after transformation [11], which stimulates murine DCs capable of driving Th2-type responses both in vitro and in vivo 
[9]. Therefore, $0-3 \mathrm{hRP}$ is the first 'nonself' preparation that the host's innate immune response will be exposed to following exposure to infective schistosomes. Their larvae infect the host via the skin where they stimulate a rapid inflammatory response accompanied by the migration of antigen-presenting cells (APCs) from the epidermis and dermis to the draining lymph nodes [12-15]. DCs matured with 0-3hRP exhibit limited up-regulation of MHC class II, CD40 and CD86, and suboptimal production of interleukin- 6 (IL-6) and IL-12/23p40 [9, 10, 16], while activation of macrophages with 0-3hRP occurs via a MyD88-dependent pathway which is only partially dependent upon toll-like receptor (TLR)-4 [17]. However, these studies did not identify a phenotype of DC that characterises their potent ability to drive Th2-type responses. The question remains as to whether proTh2 DCs have a distinct phenotype, defined by their expression of a unique profile of signature molecules, enabling them to participate actively in the induction of Th2 responses $[6,7,18]$, or resemble immature DCs, stimulating Th2 immunity via a 'default' pathway that develops in the absence of Th1-inducing stimuli [19, 20].

The present study examined the soluble proteome of immature DCs compared to pro-Th2 DCs stimulated with schistosome 0-3hRP and pro-Th1 DCs stimulated with lipopolysaccharide (LPS) using 2-DE in association with MS/MS. Our study demonstrates that pro-Th2 DCs exhibit a proteome that is intermediate between that of immature DCs and pro-Th1 DCs in terms of 'new' protein spots and 'regulated' protein spots. The differential regulation of protein spots identified by MALDI-MS/MS as having cytoskeletal and morphological functions suggests that pro-Th2 DCs have a 'limited maturation' phenotype, which is confirmed by physical microscopic examination of DC morphology.

\section{Materials and methods}

\subsection{Animals and generation of DCs from bone marrow (BM)}

Female C57BL/6 strain mice were bred and housed at the University of York. All experiments were carried out in accordance with the guidelines of the United Kingdom Animals (Scientific Procedures) Act 1986. The research involving animals was approved by the University of York Ethics Committee. Bone marrow-derived dendritic cells (BM-DCs) were prepared as previously described [9]. This protocol generates DCs that can drive Th1 or Th2 immune responses following maturation with different stimuli.

\subsection{Microbial and parasite material}

The parasite-derived preparation 0-3hRP from transformed Schistosoma mansoni cercariae was prepared as described previously $[9,11,21]$ and concentrated 25 -fold using a $5 \mathrm{kDa}$ molecular weight cut-off Ultrafree-15 unit (Millipore, Watford, UK). LPS is derived from Escherichia coli strain 0111:B4 (Sigma-Aldrich, Poole, UK).

\subsection{DC stimulation and maturation}

Immature BM-DCs were collected after 6 days of culture and seeded into 24-well plates (Nalge Nunc, Naperville, USA) at $1 \times 10^{6} / \mathrm{mL}$ in RPMI medium containing $10 \%$ low endotoxin FCS plus $20 \mathrm{ng} / \mathrm{mL}$ granulocyte-macrophage colony-stimulating factor (GM-CSF) (Peprotech, London, UK). We consider these cells more relevant for analysis of maturation in response to microbial stimulation rather than more mature BM-DCs cultured for up to 10 days. The immature BM-DCs were then cultured for $18 \mathrm{~h}$ either alone (Medium-DCs), in the presence of $40 \mu \mathrm{g} / \mathrm{mL} 0-3 \mathrm{hRP}$ plus $3 \mu \mathrm{g} / \mathrm{mL}$ polymyxin B (Sigma-Aldrich; 0-3hRP-DCs), or in the presence of $10 \mathrm{ng} / \mathrm{mL}$ LPS (LPS-DCs) as described previously [9]. After overnight culture, the majority of BM-DCs were nonadherent (e.g. $62 \%$ of Medium DCs, $76 \%$ of $0-3$ hRP-DCs and $81 \%$ of LPS-DCs), or had adhered to the plastic surface. Nonadherent cells were recovered by rinsing with warm PBS whereas adherent cells were harvested by gently scraping with the bung of a $1 \mathrm{~mL}$ syringe; together the cells were pooled for each maturation stimulus and then used for proteomic analysis. On average, regardless of the maturation stimulus, $73 \pm 4 \%$ of the cells plated on day 6 were recovered after overnight maturation; they were then between $60-76 \%$ $\mathrm{CD}_{11 \mathrm{c}^{+}}$and $74-80 \% \mathrm{MHC}$ class $\mathrm{II}^{+}$. Aliquots of $5 \times 10^{6}$ matured DCs were washed with cold PBS ( $\mathrm{pH} 7.2$ ), prior to the addition of $20 \mu \mathrm{L}$ of 20 -fold concentrated General Use Protease Inhibitor Cocktail (Sigma-Aldrich) prior to storage at $-20^{\circ} \mathrm{C}$.

\subsection{DC phenotyping}

Flow cytometric analysis of cell surface markers was performed using specific $\mathrm{mAbs}$ or an irrelevant isotype-matched mAb. BM-DCs were blocked with normal rabbit serum $\left(10 \mu \mathrm{L} / 10^{6}\right.$ cells) in PBS $0.1 \%$ BSA and then incubated with directly conjugated mAbs $\left(1 \mu \mathrm{g} / 10^{6}\right.$ cells $)$ recognising CD11c (HL3), MHC class II (I-A/I-E, M5/114.15.2), CD40 (3/23, all BD Pharmingen, Oxford, UK) or CD86 (RMMP-2, CaltagMedsystems, Buckingham, UK). Phenotypic data were acquired using a Cyan flow cytometer (Dakocytomation, UK) and analysed with Summit ${ }^{\circledR}$ software.

\subsection{Preparation of DC soluble proteins}

Cellular pellets were ground into rehydration buffer (7 M urea, $2 \mathrm{M}$ thiourea, $4 \% \mathrm{w} / \mathrm{v}$ CHAPS (Sigma-Aldrich), $10 \mathrm{mM}$ Tris pH 7.5 and trace bromophenol blue) with a pellet pestle motor $^{\circledR}$ (Sigma-Aldrich). Particulate material was removed by centrifugation at $25000 \mathrm{~g}, 20^{\circ} \mathrm{C}$ for $15 \mathrm{~min}$ and the supernatant containing soluble proteins collected. Sample volumes were increased to $350 \mu \mathrm{L}$ using rehydration 
buffer containing DTT and resolytes pH 3-10 (SigmaAldrich) sufficient to give final concentrations of $65 \mathrm{mM}$ and $0.8 \%$, respectively. 2 -D electrophoretic separations of the soluble proteins from $5 \times 10^{6} \mathrm{DCs}$ were used for quantitative analysis, whereas separations of the soluble proteins from $15 \times 10^{6}$ DCs were used for mass spectrometric analysis. Three separate cultures of DCs were matured with each of the different stimuli described above. The soluble protein content of $5 \times 10^{6} \mathrm{DC}$ pellets was $153 \pm 38 \mu \mathrm{g}$ for MediumDCs, $154 \pm 35 \mu \mathrm{g}$ for $0-3 \mathrm{hRP}-\mathrm{DCs}$ and $149 \pm 35 \mu \mathrm{g}$ for LPSDCs (determined using Coomassie Plus 200 reagent, Perbio).

\subsection{2-DE and image analysis}

IEF, storage, equilibration and SDS-PAGE of DC soluble protein samples were performed as previously described [21]. Large $\left(18 \times 18 \times 0.1 \mathrm{~cm}^{3}\right)$ gels of Medium-DCs, $0-3 \mathrm{hRP}-\mathrm{DCs}$ and LPS-DCs were stained with SYPRO Ruby (BioRad, Hemel Hampstead, UK). Images were captured using a Molecular Imager FX (BioRad). Three biological replicates, produced from three independent DC cultures, were run for each DC type simultaneously (i.e. nine gels in total). Phoretix 2D Evolution software (Nonlinear Dynamics, Newcastle, UK) was used to generate an average 2-DE image for each DC type; each spot must have been matched between at least two of the three images for inclusion. Outlier data points were not removed. Image analysis was carried out as described [11] except that the relative protein expression levels were assessed by using the mean normalised spot volumes to calculate the fold-difference between matched spots in Medium-DCs, 0-3hRP-DCs and LPS-DCs. Spots were judged to be differentially expressed where there was a two-fold or greater difference in the average normalised volume of matched spots. A one-way ANOVA test was performed within the software for matched spots and where $p<0.05$, the expression changes were considered significant.

\subsection{Mass spectrometric analysis and database searching}

Spots that were differentially expressed were chosen for detailed investigation, in addition to spots specific to a particular DC type, and the 20 most abundant spots in each type of gels, hereafter termed the 'top 20' spots. Gels were stained using Bio-Safe CBB G250 stain (BioRad) before spots of interest were manually excised and digested 'in-gel' with trypsin, and resulting peptides spotted onto MALDI target plates [11]. A 4700 Proteomics Analyser with TOF-TOF Optics (Applied Biosystems, Framingham, MA, USA) was used to obtain MALDI-MS/MS spectra of tryptic peptides in reflector positive mode [11], with the ten most intense peaks in the MS spectrum automatically selected for fragmentation. All peptides selected for fragmentation were singly charged as this is the dominant species produced by the 4700 . MS/MS data from each in-gel digest were processed by GPS Explorer soft- ware v3.0 (Applied Biosystems) to provide peak lists containing all masses from 60 up to 20 Da below the precursor mass with a minimum $\mathrm{S} / \mathrm{N}$ of 20 . These were submitted to MASCOTv2.0 (Matrix Science, London, UK) and searched against the CDS (Celera Discovery System ${ }^{\mathrm{TM}}$ ) mouse database (65 307 protein entries, a subset of National Centre for Biotechnology Information (NCBI), released in 2002) which contains all of the mouse genome protein encoding genes reannotated with Gene Ontology information (http://www.geneontology.org). We chose to search against this database firstly because it contains these useful annotations and also because it is more comprehensive than the NCBI database (http:// www.ncbi.nlm.nih.gov/, 3044223 protein entries, released in 2005) in which not all predicted protein coding genes from the genome will necessarily be present. Search parameters specified only tryptic cleavages and allowed for up to one missed site, the fixed carbamidomethylation of cysteine, and the variable oxidation of methionine; precursor and product ion mass error tolerance was $\pm 0.1 \mathrm{Da}$. A protein was considered positively identified if the GPS Explorer total ion score confidence interval exceeded $99.9 \%$ (generated by GPS Explorer on the basis of the MASCOTion scores) and if at least one peptide had a MASCOTexpectation value of less than 0.05 meaning that the probability of a random match is much less than 0.05 . Protein identities were confirmed by searching against the NCBI database. The NCBI accession number is given for each match.

Where there was redundancy in the database, i.e. one protein sequence was annotated with different accession numbers, we used the most recently updated one, after sequence alignment verified their identity. In addition, to ensure correct assignment of peptides to an individual member of a protein family, all family member protein sequences were aligned and, in all cases, multiple peptides unambiguously identified that particular member. Due to the high homology of the actin species $(>87 \%)$, it was impossible to distinguish between the different isoforms $(\alpha$, $\beta$ or $\gamma$ ) on the basis of the peptides fragmented. Therefore, we have simply named all spots 'actin' and listed the accession number as the 'top hit' as determined by MASCOT.

\subsection{Imaging of DC morphology}

For imaging, BM-DCs were left to settle gently onto sterile coverslips during overnight maturation. Adherent and nonadherent cells were recovered as described above.

For differential interference contrast (DIC) light microscopy, cells were fixed in 1\% paraformaldehyde and mounted with $25 \mu \mathrm{L}$ of Mowiol (Calbiochem, Nottingham, UK) onto poly-L-lysine slides. Slides were left to harden overnight in the dark before being examined with a Zeiss Axioplan 2M microscope equipped with DIC (objective plan-Apochromatic 63x/1.4 Oil DIC I).

For scanning electron microscopy (SEM), adherent cells on Thermanox coverslips (Nalge Nunc) and nonadherent cells in suspension were fixed in $2.5 \%$ glutaraldehyde, $4 \%$ 
formaldehyde in $100 \mathrm{mM}$ sodium phosphate buffer, $\mathrm{pH}$ 7.2. Nonadherent cells were then collected onto $0.4 \mu \mathrm{m}$ membranes (Millipore). Both adherent and nonadherent cells were dehydrated through a series of ethanol with a final treatment with $100 \%$ hexamethyldisilazane and finally coated with gold/palladium before being observed using $5 \mathrm{kV}$ in a scanning electron microscope (JSM-6490LV, JEOL, Welwyn Garden City, UK).

In order to visualise actin filaments by phalloidin staining, cells adherent onto glass coverslips were fixed in 3.7\% paraformaldehyde, quenched twice in $50 \mathrm{mM}$ ammonium chloride and permeabilised with $0.2 \%$ Triton X-100 for 5 min. Cells were then blocked with $2 \%$ goat serum in $0.5 \%$ BSA for $1 \mathrm{~h}$ and treated with $0.2 \mu \mathrm{g} / \mathrm{mL}$ tetramethyl-rhodamine B isothiocyanate (TRITC)-labelled phalloidin (SigmaAldrich) for $1 \mathrm{~h}$. Confocal images were obtained using a confocal laser-scanning microscope (objective plan-Apochromatic 63x/1.4 Oil DIC I, Zeiss Axioplan 2M microscope) fitted with appropriate filter sets.

\section{Results}

\subsection{Phenotypic characterisation of matured DCs}

Immature BM-DCs were cultured overnight in medium alone (Medium-DCs) or stimulated with 0-3hRP (0-3hRPDCs) or LPS (LPS-DCs). This resulted in increased expression (in terms of overall percentage of positive cells, and/or the median fluorescent intensity of staining) of MHC class II, CD86 and CD40 molecules at the surface of the 0-3hRPDCs and LPS-DCs relative to the cells matured with medium only (Fig. 1). Expression of each marker was also greater in LPS-DCs compared to 0-3hRP-DCs.

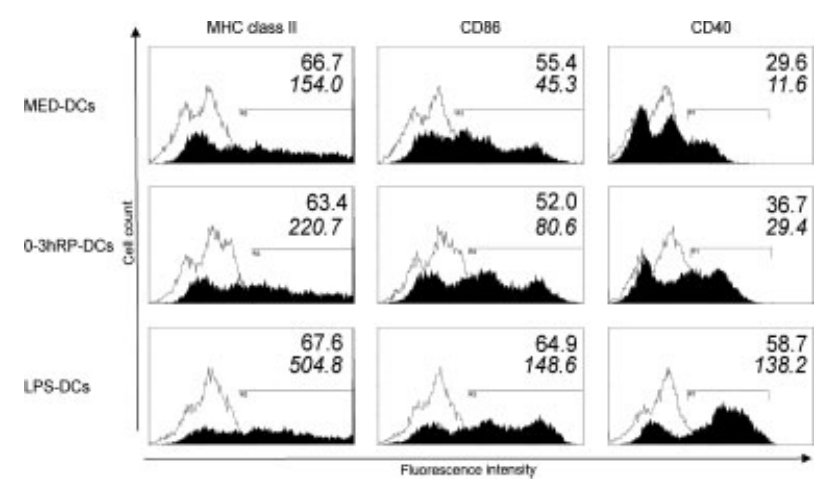

Figure 1. DC phenotyping. Flow cytometric analysis of $\mathrm{MHC}$ class II, CD86 and CD40 expression performed using specific mAbs (closed histograms) or isotype-matched mAbs (open histogram) on Medium-DCs (top row), 0-3hRP-DCs (middle row) and LPS-DCs (bottom row). Results are shown as histograms representing the cell number relative to the fluorescence intensity. The numbers given for each histogram are the percentage of positive cells (top) and the median fluorescent intensity (bottom, in italics).

\subsection{2-DE profiles of differentially matured DCs}

The average 2-DE images $(n=3)$ generated by Phoretix 2D Evolution were visualised for immature DCs (Medium-DCs), pro-Th2 DCs (0-3hRP-DCs) and pro-Th1 DCs (LPS-DCs; Figs. 2A-C). The separations for each cell type were highly reproducible with $90.06 \pm 5.37 \%$ spots matching for Medium-DCs, $\quad 95.81 \pm 1.53 \%$ for $0-3$ hRP-DCs and $92.22 \pm 3.92 \%$ for LPS-DCs, with their respective reference gel. The number of spots detected per average gel was 579 for Medium-DCs (Fig. 2A), 684 for 0-3hRP-DCs (Fig. 2B) and 1009 for LPS-DCs (Fig. 2C) with $92.96 \pm 3.52 \%$ matching with the experiment reference gel.

We have arbitrarily numbered 83 spots which were successfully identified by MALDI-MS/MS (Figs. 2A-C) (detailed identification information is given in Supporting Information Table S1 (for all identified proteins) and Fig. S1 (MS/MS spectra of single-peptide proteins)). Attempts were made to analyse all spots of interest that were visible after BioSafe Coomassie staining, however the low abundance of many spots prevented their identification.

\subsection{Spot distribution between the differentially matured DCs}

There was a great similarity in spot pattern between the three differentially matured DC proteomes since 424 spots were shared between them (Fig. 3). However, we also observed a major increase in pro-Th1 LPS-DCs compared to MediumDCs $(500$ spots) but only a limited increase in pro-Th2 03 hRP-DCs compared to Medium-DCs (258 spots). Therefore, the proteomic profile of LPS-DCs appears to be more complex than the immature Medium-DCs, or 0-3hRP-DCs. Moreover, although only 68 spots were specific to MediumDCs and 82 were specific to $0-3$ hRP-DCs, a much greater number, 324 were specific to LPS-DCs.

\subsection{Identification of proteins from the most abundant spots}

The 20 most abundant spots, (based on their normalised volume, in each type of DC) were identified by MALDI-MS/ MS revealing 27 different spots; 13 of which were shared between the three types of DCs (Table 1). These spots represented only 19 different proteins, three of which were present as two or more spots. They were largely cytoskeletal proteins $(30 \%)$, selective calcium-binding proteins $(22 \%)$ and enzymes mainly involved in cell metabolism (18\%). Some spots were abundant in only one or two type(s) of DCs. For example, the cytoskeletal protein vimentin (spot \#14) was among the 'top 20' spots of Medium-DCs only; prohibitin (\#55) was only abundant in 0-3hRP-DCs and the selective calcium-binding protein S100 A10 (\#83) was among the top 20 ' spots only in LPS-DCs. Although the 'top 20' spots varied between gels, all were present in each DC type, albeit at lower relative abundances. 

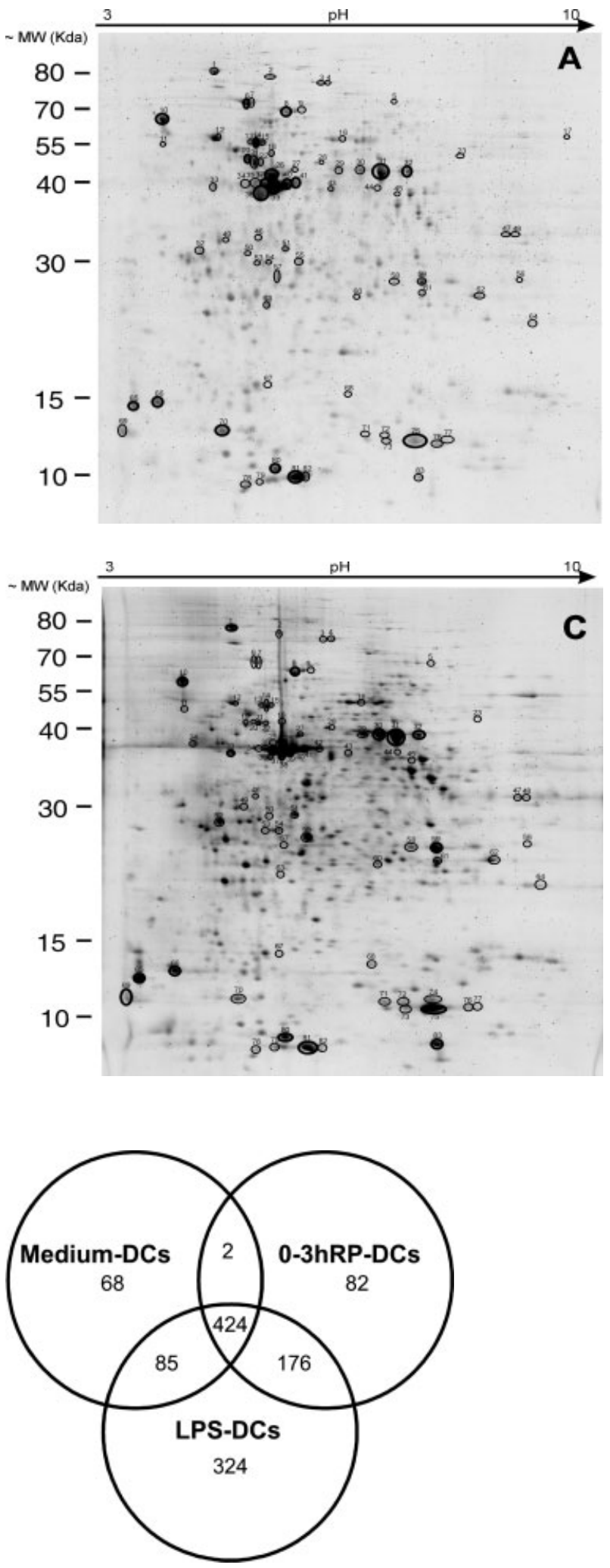

Figure 3. Venn diagram of the protein spot distribution in the average gels of Medium-, $0-3 \mathrm{hRP}$ - and LPS-DCs. The total number of spots detected with Phoretix 2D Evolution software was divided to show the extent of overlap between the three types of DCs.

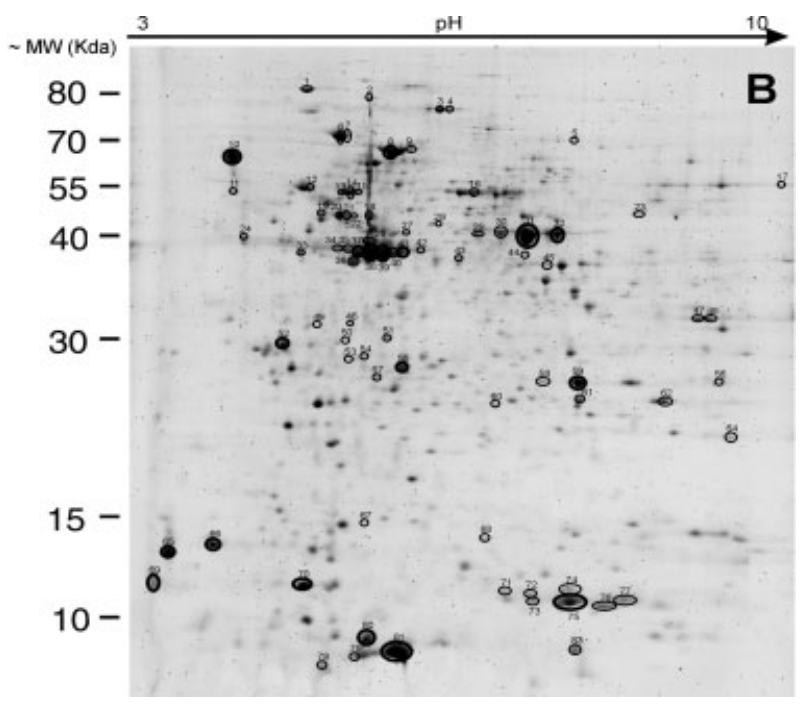

Figure 2. SYPRO Ruby-stained average images of 2-DE of differentially matured DCs. The soluble proteins separated by 2-DE were extracted from $5 \times 10^{6} \mathrm{DCs}$ matured for $18 \mathrm{~h}$ either alone (immature Medium-DCs) (A), in the presence of 0-3hRP (0-3hRPDCs) (B) or in the presence of LPS (LPS-DCs) (C). We have arbitrarily numbered and circled 83 spots which were the 'top 20 ' spots (thick circle) and/or differentially expressed spots (thin circle) and successfully identified by MALDI-MS/MS (detailed identification information given in Supporting Information Table S1). The $\mathrm{pH}$ gradient in the first dimension ranged from 3 to 10 . The second dimension was a 9-16\% gradient polyacrylamide gel with apparent protein molecular weights indicated on the figure.

\subsection{Identification of the differentially expressed proteins}

Numerous changes in the relative abundance of particular proteins were reproducibly detected. The number of matched spots with a normalised volume variation greater (or equal) than two-fold between 0-3hRP-DCs and Medium-DCs was 91 (34 increased and 57 decreased). There were 166 differentially expressed spots between LPS-DCs and Medium-DCs (44 increased and 122 decreased). Therefore, the number of changes suggests that pro Th2 0-3hRP-DCs are closer to Medium-DCs than LPS-DCs in terms of proteomic profile. Of the spots differentially expressed between 0-3hRP-DCs and Medium-DCs, 29 were successfully identified (13 up-regulated, 16 downregulated; Table 2) while between LPS-DCs and MediumDCs, 44 were identified ( 9 up-regulated, 35 down-regulated; Table 3). 
Table 1. Identities of the 'top 20' proteins from Medium-, 0-3hRP- and LPS-DCs

\begin{tabular}{|c|c|c|c|c|c|c|c|}
\hline $\begin{array}{l}\text { Spot } \\
\text { no. }{ }^{\text {a) }}\end{array}$ & Putative protein & $\begin{array}{l}\text { NCBI } \\
\text { accession no. }\end{array}$ & Molecular function ${ }^{\text {b) }}$ & Biological process ${ }^{c)}$ & Medium-DCs & 0-3hRP-DCs & LPS-DCs \\
\hline 8 & $\begin{array}{l}\text { Heat shock cognate } \\
71 \mathrm{kDa}\end{array}$ & P08109 & Chaperone & $\begin{array}{l}\text { Protein folding; protein } \\
\text { complex assembly }\end{array}$ & $\bullet$ & $\bullet$ & $\bullet$ \\
\hline 10 & Calreticulin prec. & P14211 & $\begin{array}{l}\text { Select calcium-binding } \\
\text { protein }\end{array}$ & Protein folding & $\bullet$ & $\bullet$ & $\bullet$ \\
\hline 31 & $\alpha$-Enolase & P17182 & Enzyme & Glycolysis & $\bullet$ & $\bullet$ & $\bullet$ \\
\hline 32 & $\alpha$-Enolase & P17182 & Enzyme & Glycolysis & ○ & - & ○ \\
\hline 37 & Actin & CAA27396 & Cytoskeletal protein & Cell structure & $\bullet$ & $\bullet$ & $\bullet$ \\
\hline 38 & Actin & CAA27396 & Cytoskeletal protein & Cell structure & 0 & 0 & 0 \\
\hline 39 & Actin & CAA27396 & Cytoskeletal protein & Cell structure & $\bullet$ & $\bullet$ & $\bullet$ \\
\hline 41 & Actin & CAA27396 & Cytoskeletal protein & Cell structure & 0 & 0 & 0 \\
\hline 65 & Calmodulin 2 & NP_031615 & $\begin{array}{l}\text { Select calcium-binding } \\
\text { protein }\end{array}$ & $\begin{array}{l}\text { Calcium mediated } \\
\text { signaling }\end{array}$ & $\bullet$ & $\bullet$ & $\bullet$ \\
\hline 66 & $\begin{array}{l}\text { Myosin light chain, } \\
\text { alkali, nonmuscle }\end{array}$ & NP_034990 & $\begin{array}{l}\text { Select regulatory } \\
\text { molecule/cytoskeletal } \\
\text { protein }\end{array}$ & Muscle contraction & $\bullet$ & $\bullet$ & $\bullet$ \\
\hline 75 & $\begin{array}{l}\text { S100 calcium-binding } \\
\text { protein A9 }\end{array}$ & NP_033140 & $\begin{array}{l}\text { Select calcium-binding } \\
\text { protein }\end{array}$ & Immunity and defence & $\bullet$ & ○ & $\bullet$ \\
\hline 80 & $\begin{array}{l}\text { Triose-phosphate } \\
\text { isomerase }\end{array}$ & P17751 & Enzyme & $\begin{array}{l}\text { Glycolysis; gluconeogenesis; } \\
\text { pentose-P shunt }\end{array}$ & $\bullet$ & $\bullet$ & $\bullet$ \\
\hline 81 & $\begin{array}{l}\text { S100 calcium-binding } \\
\text { protein } A 8\end{array}$ & NP_038678 & $\begin{array}{l}\text { Select calcium-binding } \\
\text { protein }\end{array}$ & $\begin{array}{l}\text { Macrophage-mediated } \\
\text { immunity }\end{array}$ & $\bullet$ & $\bullet$ & $\bullet$ \\
\hline 70 & Thioredoxin 1 & NP_035790 & Unclassified & - & $\bullet$ & $\bullet$ & - \\
\hline 59 & $\begin{array}{l}\text { Phosphoglycerate } \\
\text { mutase } 1\end{array}$ & Q9DBJ1 & Enzyme & Glycolysis & - & $\bullet$ & $\bullet$ \\
\hline 69 & Calmodulin 2 & NP_031615 & $\begin{array}{l}\text { Select calcium-binding } \\
\text { protein }\end{array}$ & Calcium mediated signaling & - & $\bullet$ & $\bullet$ \\
\hline 6 & $\begin{array}{r}\text { Grp 78, heat shock } \\
70 \mathrm{kD} \text { a protein } 5\end{array}$ & 09DC41 & Chaperone & $\begin{array}{l}\text { Protein folding; protein } \\
\text { complex assembly }\end{array}$ & $\bullet$ & - & - \\
\hline 14 & Vimentin & NP_035831 & Cytoskeletal protein & Cell structure & - & - & - \\
\hline 20 & $\begin{array}{c}\text { ATP synthase } \\
\beta \text {-subunit }\end{array}$ & AAB86421 & Transporter/enzyme & $\begin{array}{l}\text { Purine metabolism/cation } \\
\text { transport }\end{array}$ & $\bullet$ & - & - \\
\hline 26 & Actin & CAA27396 & Cytoskeletal protein & Cell structure & $\bullet$ & - & - \\
\hline 40 & Actin & CAA31455 & Cytoskeletal protein & Cell structure & 0 & - & - \\
\hline 52 & Tropomyosin $\beta$ & 111213 & Cytoskeletal protein & Muscle contraction & - & $\bullet$ & - \\
\hline 55 & Prohibitin & P24142 & Unclassified & $\begin{array}{l}\text { DNA metabolism and } \\
\text { replication; cell } \\
\text { cycle control }\end{array}$ & - & $\bullet$ & - \\
\hline 1 & $\begin{array}{l}\text { Tumour rejection } \\
\text { antigen gp96 }\end{array}$ & CAJ82870 & Unclassified & Stress response & - & - & $\bullet$ \\
\hline 30 & $\alpha$-Enolase & P17182 & Enzyme & Glycolysis & - & - & $\bullet$ \\
\hline 33 & Laminin receptor 1 & 08BNL2 & $\begin{array}{l}\text { Nucleic acid-binding } \\
\text { protein }\end{array}$ & Protein biosynthesis & - & - & $\bullet$ \\
\hline 83 & $\begin{array}{l}\text { S100 calcium-binding } \\
\text { protein A10 }\end{array}$ & NP_033138 & $\begin{array}{l}\text { Select calcium-binding } \\
\text { protein }\end{array}$ & Developmental processes & - & - & $\bullet$ \\
\hline
\end{tabular}

- Means that the spot belongs to the 'top $20^{\prime}$ spots in the different groups of DCs. The table shows first the spots shared by the three DC types, secondly the spots expressed by Medium- and 0-3hRP-DCs only, then the spots shared by 0-3hRP- and LPS-DCs, and finally the spots that are among the 'top 20' in only one of the DC type (Medium-, 0-3hRP- and LPS-DCs). prec., precursor; Grp, glucose-regulated protein.

a) Numbers identify spots in Fig. 2 .

b) Molecular function(s) of the identified proteins.

c) The biological process(es) in which these proteins are involved are determined by MASCOT searching against the CDS mouse database. 
Table 2. Identities of the differentially expressed proteins between 0-3hRP-DCs and Medium-DCs.

\begin{tabular}{|c|c|c|c|c|c|}
\hline Spot no. ${ }^{\text {a) }}$ & Putative protein & Fold difference ${ }^{\text {b) }}$ & NCBI accession no. & Molecular function ${ }^{c)}$ & Biological process ${ }^{\mathrm{d})}$ \\
\hline \multicolumn{6}{|c|}{ Up-regulated } \\
\hline 5 & Ezrin & 3.2 & P26040 & Cytoskeletal protein & Cell structure \\
\hline 17 & $\begin{array}{l}\text { ATP synthase } \alpha \text { chain, } \\
\text { mitochondrial prec. }\end{array}$ & 4.3 & 003265 & Enzyme & $\begin{array}{l}\text { Nucleoside, nucleotide and nucleic } \\
\text { acid metabolism }\end{array}$ \\
\hline 18 & Actin & 2.7 & CAA27396 & Cytoskeletal protein & Cell structure \\
\hline 29 & $\alpha$-Enolase & 3.6 & P17182 & Enzyme & Glycolysis \\
\hline 43 & Actin* $^{*}$ & 3.1 & CAA31455 & Cytoskeletal protein & Cell structure \\
\hline 45 & Arginase 1 & 2.3 & 061176 & Enzyme & Amino acid catabolism \\
\hline 54 & Cathepsin B & 3.2 & $1701299 \mathrm{~A}$ & Unclassified & Protein metabolism and modification \\
\hline 56 & Phosphoglycerate mutase 1 & 3.8 & 09DBJ1 & Enzyme & Glycolysis \\
\hline 61 & $\begin{array}{l}\text { S100 calcium-binding } \\
\text { protein A11 }\end{array}$ & 3.8 & XP_357005 & $\begin{array}{l}\text { Select calcium-binding } \\
\text { protein }\end{array}$ & $\begin{array}{l}\text { DNA metabolism and replication/ } \\
\text { tumour suppressor }\end{array}$ \\
\hline 68 & Superoxide dismutase 1 & 5.8 & XP_128337 & Enzyme & Immunity and defence \\
\hline 71 & $\begin{array}{l}\text { S100 calcium-binding } \\
\text { protein } \mathrm{A}^{*}\end{array}$ & 2.0 & NP_033140 & $\begin{array}{l}\text { Select calcium-binding } \\
\text { protein }\end{array}$ & Immunity and defence \\
\hline 72 & $\begin{array}{l}\text { S100 calcium-binding } \\
\text { protein A9 }\end{array}$ & 2.5 & NP_033140 & $\begin{array}{l}\text { Select calcium-binding } \\
\text { protein }\end{array}$ & Immunity and defence \\
\hline 77 & $\begin{array}{l}\text { S100 calcium-binding } \\
\text { protein A9 }\end{array}$ & 3.7 & NP_033140 & $\begin{array}{l}\text { Select calcium-binding } \\
\text { protein }\end{array}$ & Immunity and defence \\
\hline \multicolumn{6}{|c|}{ Down-regulated } \\
\hline 2 & Moesin & -7.5 & P26041 & Cytoskeletal protein & Cell structure \\
\hline 14 & Vimentin & -3.0 & NP_035831 & Cytoskeletal protein & Cell structure \\
\hline 15 & Vimentin & -5.9 & NP_035831 & Cytoskeletal protein & Cell structure \\
\hline 20 & ATP synthase $\beta$-subunit & -2.1 & AAB86421 & Transporter/enzyme & Purine metabolism/cation transport \\
\hline 21 & Vimentin & -3.6 & NP_035831 & Cytoskeletal protein & Cell structure \\
\hline 22 & Actin & -9.7 & 109522 & Cytoskeletal protein & Cell structure \\
\hline 26 & Actin** & -3.1 & CAA27396 & Cytoskeletal protein & Cell structure \\
\hline 27 & Actin & -4.3 & Q8BFZ3 & Cytoskeletal protein & Cell structure \\
\hline 39 & Actin & -4.4 & CAA27396 & Cytoskeletal protein & Cell structure \\
\hline 40 & Actin & -3.8 & CAA31455 & Cytoskeletal protein & Cell structure \\
\hline 44 & $\alpha$-Enolase & -2.0 & P17182 & Enzyme & Glycolysis \\
\hline 49 & Annexin A5 & -3.5 & P48036 & $\begin{array}{l}\text { Select calcium-binding } \\
\text { protein }\end{array}$ & $\begin{array}{l}\text { Lipid, fatty acid and steroid meta- } \\
\text { bolism/immunity and defence }\end{array}$ \\
\hline 50 & Cathepsin $B^{*}$ & -9.2 & 1701299A & Unclassified & Protein metabolism and modification \\
\hline 57 & Actin & -3.6 & CAA27396 & Cytoskeletal protein & Cell structure \\
\hline 67 & $\begin{array}{l}\text { Eukaryotic translation } \\
\text { initiation factor } 5 \mathrm{~A}\end{array}$ & -3.1 & BAB27641 & $\begin{array}{l}\text { Nucleic acid-binding } \\
\text { protein }\end{array}$ & Protein biosynthesis \\
\hline 78 & Cathepsin C & -2.1 & 08BOL3 & Enzyme & Proteolysis \\
\hline
\end{tabular}

A one-way ANOVA test was performed. ${ }^{*} p \leq 0.05,{ }^{* *} p \leq 0.00001$. prec., precursor.

a) Numbers identify spots in Fig. 2.

b) Fold-changes between matched spots in 0-3hRP-DCs and Medium-DCs 2-DE were calculated as a ratio of the mean normalised spot volumes. Spots were judged to be differentially expressed where there was a two-fold or greater difference.

c) Molecular function(s) of the identified proteins and d) the biological process(es) in which these proteins are involved are determined by MASCOT searching against the CDS mouse database.

Among the differentially expressed identified spots in 0-3hRP-DCs (cf. Medium-DCs), statistically significant increased fold-changes were detected for the cytoskeletal protein actin (\#43, +3.1-fold) and S100 A9 (\#71, +2.0, Table 2). Significant decreased expression was observed for actin (\#26, -3.1-fold) and for the enzyme cathepsin B $(\# 50,-9.2)$. Additional differences, while not statistically significant, were substantial (e.g. superoxide dismutase 1 ,
\#68, +5.8; moesin, \#2, -7.5; vimentin, \#15, -5.9; actin, $\# 22,-9.7)$.

In parallel, significant increased expression of spots in LPS-DCs ( $c f$. Medium-DCs) included the enzyme triosephosphate isomerase $(\# 62,+3.8)$ and S100 A9 (\#71, +3.2 and \#73, +2.2; Table 3). Grp78 (\#7, -3.1), the precursor of the selective calcium-binding protein calreticulin (\#11, -2.0), vimentin (\#13, -3.6), actin (\#26, -5.3 and \#35, -2.5), 
Table 3. Identities of the differentially expressed proteins between LPS-DCs and Medium-DCs

\begin{tabular}{|c|c|c|c|c|c|}
\hline Spot no. ${ }^{\text {a) }}$ & Putative protein & Fold difference ${ }^{b)}$ & NCBI accession no. & Molecular function ${ }^{\mathrm{c})}$ & Biological process $^{d)}$ \\
\hline \multicolumn{6}{|c|}{ Up-regulated } \\
\hline 58 & Phosphoglycerate mutase 1 & 2.2 & Q9DBJ1 & Enzyme & Glycolysis \\
\hline 61 & S100 calcium-binding protein A11 & 4.8 & XP_357005 & $\begin{array}{l}\text { Select calcium-binding } \\
\text { protein }\end{array}$ & $\begin{array}{l}\text { DNA metabolism and replica- } \\
\text { tion/tumour suppressor }\end{array}$ \\
\hline 62 & Triose-phosphate isomerase* & 3.8 & P17751 & Enzyme & $\begin{array}{l}\text { Glycolysis; gluconeogenesis; } \\
\text { pentose-P shunt }\end{array}$ \\
\hline 64 & Peroxiredoxin 1 & 2.6 & Q9CWI2 & Enzyme & $\begin{array}{l}\text { Antioxydation and free radical } \\
\text { removal }\end{array}$ \\
\hline 68 & Superoxide dismutase 1 & 6.8 & XP_128337 & Enzyme & Immunity and defence \\
\hline 71 & S100 calcium-binding protein A9* & 3.2 & NP_033140 & $\begin{array}{l}\text { Select calcium-binding } \\
\text { protein }\end{array}$ & Immunity and defence \\
\hline 72 & S100 calcium-binding protein A9 & 2.2 & NP_033140 & $\begin{array}{l}\text { Select calcium-binding } \\
\text { protein }\end{array}$ & Immunity and defence \\
\hline 73 & S100 calcium-binding protein $A 9^{*}$ & 2.2 & NP_033140 & $\begin{array}{l}\text { Select calcium-binding } \\
\text { protein }\end{array}$ & Immunity and defence \\
\hline 77 & S100 calcium-binding protein A9 & 2.1 & NP_033140 & $\begin{array}{l}\text { Select calcium-binding } \\
\text { protein }\end{array}$ & Immunity and defence \\
\hline \multicolumn{6}{|c|}{ Down-regulated } \\
\hline 1 & Tumour rejection antigen gp96 & -3.0 & CAJ82870 & Unclassified & Stress response \\
\hline 2 & Moesin & -4.4 & P26041 & Cytoskeletal protein & Cell structure \\
\hline 3 & Gelsolin & -2.3 & AAH23143 & $\begin{array}{l}\text { Select calcium-binding } \\
\text { protein/cytoskeletal } \\
\text { protein }\end{array}$ & Cell structure \\
\hline 4 & Gelsolin & -7.3 & AAH23143 & $\begin{array}{l}\text { Select calcium-binding } \\
\text { protein/cytoskeletal } \\
\text { protein }\end{array}$ & Cell structure \\
\hline 6 & $\begin{array}{l}\text { Grp } 78 \text {, Heat shock } 70 \mathrm{kDa} \\
\quad \text { protein } 5\end{array}$ & -4.6 & Q9DC41 & Chaperone & $\begin{array}{l}\text { Protein folding; protein complex } \\
\text { assembly }\end{array}$ \\
\hline 7 & $\begin{array}{l}\text { Grp } 78, \text { Heat shock } 70 \mathrm{kDa} \\
\text { protein } 5^{*}\end{array}$ & -3.1 & Q9DC41 & Chaperone & $\begin{array}{l}\text { Protein folding; protein complex } \\
\text { assembly }\end{array}$ \\
\hline 9 & Heat shock cognate 71 kDa & -3.1 & P08109 & Chaperone & $\begin{array}{l}\text { Protein folding; protein complex } \\
\text { assembly }\end{array}$ \\
\hline 10 & Calreticulin prec. & -2.3 & P14211 & $\begin{array}{l}\text { Select calcium-binding } \\
\text { protein }\end{array}$ & Protein folding \\
\hline 11 & Calreticulin prec.* & -2.0 & P14211 & $\begin{array}{l}\text { Select calcium-binding } \\
\text { protein }\end{array}$ & Protein folding \\
\hline 12 & Protein disulphide isomerase prec. & -2.1 & P09103 & Enzyme & $\begin{array}{l}\text { Protein disulphide-isomerase } \\
\text { reaction }\end{array}$ \\
\hline 13 & Vimentin*** & -3.6 & NP_035831 & Cytoskeletal protein & Cell structure \\
\hline 14 & Vimentin & -2.0 & NP_035831 & Cytoskeletal protein & Cell structure \\
\hline 15 & Vimentin & -2.2 & NP_035831 & Cytoskeletal protein & Cell structure \\
\hline 16 & $\sim$ ER-60 protease ( $\sim$ Grp 58$)$ & -2.0 & Q99'LF6 & Enzyme & $\begin{array}{l}\text { Protein disulphide-isomerase } \\
\text { reaction }\end{array}$ \\
\hline 18 & Actin & -2.5 & CAA27396 & Cytoskeletal protein & Cell structure \\
\hline 20 & ATP synthase $\beta$-subunit & -2.7 & AAB86421 & Transporter/enzyme & $\begin{array}{l}\text { Purine metabolism/cation } \\
\text { transport }\end{array}$ \\
\hline 22 & Actin & -12.1 & 109522 & Cytoskeletal protein & Cell structure \\
\hline 23 & $\alpha$-Enolase & -2.4 & NP_075608 & Enzyme & Glycolysis \\
\hline 26 & $\operatorname{Actin}^{* *}$ & -5.3 & CAA27396 & Cytoskeletal protein & Cell structure \\
\hline 33 & Laminin receptor 1 & -2.6 & Q8BNL2 & $\begin{array}{l}\text { Nucleic acid-binding } \\
\text { protein }\end{array}$ & Protein biosynthesis \\
\hline 34 & Actin & -2.9 & CAA27396 & Cytoskeletal protein & Cell structure \\
\hline 35 & Actin* $^{*}$ & -2.5 & CAA27396 & Cytoskeletal protein & Cell structure \\
\hline 39 & Actin & -3.4 & CAA27396 & Cytoskeletal protein & Cell structure \\
\hline 40 & Actin & -6.6 & CAA31455 & Cytoskeletal protein & Cell structure \\
\hline 44 & $\alpha$-Enolase & -3.3 & P17182 & Enzyme & Glycolysis \\
\hline
\end{tabular}


Table 3. Continued

\begin{tabular}{|c|c|c|c|c|c|}
\hline Spot no. ${ }^{\text {a) }}$ & Putative protein & Fold difference ${ }^{\text {b) }}$ & NCBI accession no. & Molecular function ${ }^{c)}$ & Biological process ${ }^{\mathrm{d})}$ \\
\hline 46 & Cathepsin Z & -2.4 & Q9ES94 & Enzyme & Proteolysis \\
\hline 47 & Annexin A2 & -2.0 & NP_031611 & $\begin{array}{l}\text { Select calcium-binding } \\
\text { protein }\end{array}$ & $\begin{array}{l}\text { Intracellular protein traffic/cell } \\
\text { structure and motility }\end{array}$ \\
\hline 49 & Annexin A5 & -3.1 & P48036 & $\begin{array}{l}\text { Select calcium-binding } \\
\text { protein }\end{array}$ & $\begin{array}{l}\text { Lipid, fatty acid and steroid } \\
\text { metabolism/blood clotting }\end{array}$ \\
\hline 50 & Cathepsin $\mathrm{B}^{*}$ & -5.4 & $1701299 \mathrm{~A}$ & Unclassified & $\begin{array}{l}\text { Protein metabolism and } \\
\text { modification }\end{array}$ \\
\hline 51 & Annexin A4 & -2.0 & 07TMN7 & $\begin{array}{l}\text { Select calcium-binding } \\
\text { protein }\end{array}$ & Exocytosis; endocytosis \\
\hline 53 & Cathepsin B & -3.2 & $1701299 \mathrm{~A}$ & Unclassified & $\begin{array}{l}\text { Protein metabolism and } \\
\text { modification }\end{array}$ \\
\hline 57 & Actin & -2.4 & CAA27396 & Cytoskeletal protein & Cell structure \\
\hline 63 & Actin & -2.2 & Q8BFZ3 & Cytoskeletal protein & Cell structure \\
\hline 79 & S100 calcium-binding protein A8 & -2.1 & NP_038678 & $\begin{array}{l}\text { Select calcium-binding } \\
\text { protein }\end{array}$ & Macrophage-mediated immunity \\
\hline 82 & S100 calcium-binding protein $A 8^{*}$ & -2.3 & NP_038678 & $\begin{array}{l}\text { Select calcium-binding } \\
\text { protein }\end{array}$ & Macrophage-mediated immunity \\
\hline
\end{tabular}

A one-way ANOVA test was performed: ${ }^{*} p \leq 0.05,{ }^{* *} p \leq 0.00001,{ }^{* * *} p \leq 0.000005$. gp, glycoprotein; Grp, glucose-regulated protein; prec., precursor.

a) Numbers identify spots in Fig. 2.

b) Fold-changes between matched spots in LPS-DCs and Medium-DCs 2-DE were calculated as a ratio of the mean normalised spot volumes. Spots were judged to be differentially expressed where there was a two-fold or greater difference.

c) Molecular function(s) of the identified proteins and d) the biological process(es) in which these proteins are involved are determined by MASCOT searching against the CDS mouse database.

cathepsin B (\#50, -5.4) and S100 A8 (\#82, -2.3) were all significantly down-regulated (Table 3). Additional changes $(p>0.05)$ were detected for superoxide dismutase 1 (\#68, $+6.8)$, gelsolin $(\# 4,-7.3)$ and actin $(\# 22,-12.1$ and \#40, -6.6). Therefore, many proteins $(5 / 8)$ that showed significant and/or substantial changes in 0-3hRP-DCs compared to Medium-DCs were also detected in LPS-DCs. Numerous other differences (predominantly down-regulations of protein expression) also appeared only in the pro-Th1 DCs versus the immature DCs.

We also identified differences in protein expression between 0-3hRP-DCs and LPS-DCs (Supporting Information Table S2).

\subsection{Identification of proteins specific to mature DCs}

Certain spots expressed specifically in one or two type(s) of differentially matured DCs were not shared between all of them and potentially could be unique, or 'signature' spots. Unfortunately, most of them were expressed at low levels at the LOD by CBB staining, and therefore, were difficult to identify by MALDI-MS/MS. Nevertheless, five spots were identified in 0-3hRP-DCs but not in Medium-DCs, and six were identified in LPS-DCs but not in Medium-DCs (Table 4). All of the identified spots specific for 0-3hRP-DCs ( $c f$. Medium-DCs) were also detected in LPS-DCs and, therefore were specific for mature DCs capable of stimulating T cell responses; we also identified one spot that was expressed by LPS-DCs only.

\subsection{Importance of PTMs}

A high percentage of the total differentially expressed, or unique, and identified proteins were present as multiple molecular forms $(72 \%, 47 / 65$, Table 5). These isoforms could represent PTMs of single proteins that can lead to spots with different molecular weights resulting from the addition of prosthetic groups (e.g. glycosylation), or proteolytic processing. Alternatively, spots of the same protein with different pI could be related to phosphorylation or acetylation and visualised in 2-DE as a 'train of spots'. These modifications were not characterised in the present study. Most of the isoforms of the same protein were regulated in the same direction in a specific cell type. For example, three of the four isoforms of vimentin were down-regulated in 0-3hRP-DCs (\#14, 15 and 21) and LPS-DCs (\#13, 14 and 15) versus immature DCs. However, in some cases, the multiple isoforms of the same protein was either up- or down-regulated. For instance, in 0-3hRP-DCs versus Medium-DCs, some actin spots were up-regulated (\#18 and 43) but other actin isoforms were down-regulated (\#22, 26, 27, 39, 40 and 57). This suggested that the different isoforms of a protein may have different roles during maturation of pro-Th1 and/or pro-Th2 
Table 4. Identities of the proteins specific to mature DCs

\begin{tabular}{lllll}
\hline Spot no. ${ }^{\text {a) }}$ & Putative protein & NCBI accession no. & Molecular function $^{\text {b) }}$ & Biological process $^{\text {c) }}$ \\
\hline 0-3hRP-DCs & vs. Medium-DCs & & & \\
19 & ATP synthase $\beta$-subunit* & AAB86421 & Transporter/enzyme & Purine metabolism/cation transport \\
24 & Protein disulphide isomerase A3 prec. & P27773 & Enzyme & Protein disulphide-isomerase reaction \\
36 & Actin & CAA27396 & Cytoskeletal protein & Cell structure \\
42 & Actin & $090 Z 83$ & Cytoskeletal protein & Cell structure \\
74 & S100 calcium-binding protein A9* & NP_033140 & Select calcium-binding protein & Immunity and defence \\
LPS-DCs vs. Medium-DCs & & & \\
19 & ATP synthase $\beta$-subunit* & AAB86421 & Transporter/enzyme & Purine metabolism/cation transport \\
24 & Protein disulphide isomerase A3 prec. & P27773 & Enzyme & Protein disulphide-isomerase reaction \\
25 & Actin & $08 B F Z 3$ & Cytoskeletal protein & Cell structure \\
36 & Actin & CAA27396 & Cytoskeletal protein & Cell structure \\
42 & Actin & $090 Z 83$ & Cytoskeletal protein & Cell structure \\
74 & S100 calcium-binding protein A9* & NP_033140 & Select calcium-binding protein & Immunity and defence \\
\hline
\end{tabular}

The top list shows the proteins specific to 0-3hRP-DCs and the bottom list shows the proteins specific to LPS-DCs in comparison to Medium-DCs. A one-way ANOVA test was performed: * $p \leq 0.05$. prec., precursor.

a) Numbers identify spots in Fig. 2.

b) Molecular function(s) of the identified proteins, and c) the biological process(es) in which these proteins are involved are determined by MASCOT searching against the CDS mouse database.

Table 5. Identities and distribution of protein isoforms

\begin{tabular}{|c|c|c|c|c|c|c|c|c|}
\hline \multirow[t]{3}{*}{ Molecular function } & \multirow[t]{3}{*}{ Putative protein } & \multirow{3}{*}{$\begin{array}{l}\text { Number } \\
\text { of isoforms }\end{array}$} & \multicolumn{6}{|c|}{ Distribution of isoforms } \\
\hline & & & \multicolumn{3}{|c|}{ 0-3hRP-DCs vs. Medium-DCs } & \multicolumn{3}{|c|}{ LPS-DCs vs. Medium-DCs } \\
\hline & & & Up & Down & Unique & Up & Down & Unique \\
\hline Chaperone & Grp 78 & 2 & 0 & 0 & 0 & 0 & 2 & 0 \\
\hline \multirow[t]{2}{*}{ Cytoskeletal protein } & Actin & 14 & 2 & 6 & 2 & 0 & 9 & 3 \\
\hline & Vimentin & 4 & 0 & 3 & 0 & 0 & 3 & 0 \\
\hline \multirow[t]{4}{*}{ Enzyme } & Cathepsin B & 3 & 1 & 1 & 0 & 0 & 2 & 0 \\
\hline & Phosphoglycerate mutase 1 & 2 & 1 & 0 & 0 & 1 & 0 & 0 \\
\hline & Protein disulphide isomerase prec. & 2 & 0 & 0 & 1 & 0 & 1 & 1 \\
\hline & $\alpha$-Enolase & 4 & 1 & 1 & 0 & 0 & 2 & 0 \\
\hline \multirow{4}{*}{$\begin{array}{l}\text { Select calcium-binding } \\
\text { protein }\end{array}$} & Annexin A2 & 2 & 0 & 0 & 0 & 0 & 1 & 0 \\
\hline & S100 calcium-binding protein A8 & 2 & 0 & 0 & 0 & 0 & 2 & 0 \\
\hline & S100 calcium-binding protein A9 & 6 & 3 & 0 & 1 & 4 & 0 & 1 \\
\hline & Calreticulin prec. & 2 & 0 & 0 & 0 & 0 & 2 & 0 \\
\hline $\begin{array}{l}\text { Select calcium-binding } \\
\text { protein/cytoskeletal protein }\end{array}$ & Gelsolin & 2 & 0 & 0 & 0 & 0 & 2 & 0 \\
\hline Transporter/enzyme & ATP synthase $\beta$ subunit & 2 & 0 & 1 & 1 & 0 & 1 & 1 \\
\hline
\end{tabular}

Identities of the differentially expressed and identified proteins present as multiple isoforms across all gels and their distribution in 0 3hRP-DCs vs. Medium-DCs and in LPS-DCs vs. Medium-DCs. These protein isoforms presented variations in pl, apparent molecular mass or both. Grp, glucose-regulated protein; prec., precursor.

DCs. These modifications also explained why some of the proteins identified were not detected in the area where they were expected to be according to the molecular weight and $\mathrm{p} I$ reported in the database.

\subsection{Assessment of cell morphology changes}

The morphology of the three types of differentially matured DCs (Medium-DCs, 0-3hRP-DCs and LPS-DCs) were ana- lysed to verify the association between changes in cytoskeletal protein expression and cell shape.

DIC light microscopy revealed that nonadherent Medium-DCs have a rounded morphology whereas LPS-DCs have a more irregular morphology with numerous folds and projections; 0-3hRP-DCs showed an intermediate morphology (Fig. 4a). Adherent Medium-DCs exhibited an elongated bipolar morphology (Fig. 4b), whereas adherent LPS-DCs displayed a more rounded morphology characteristic of 

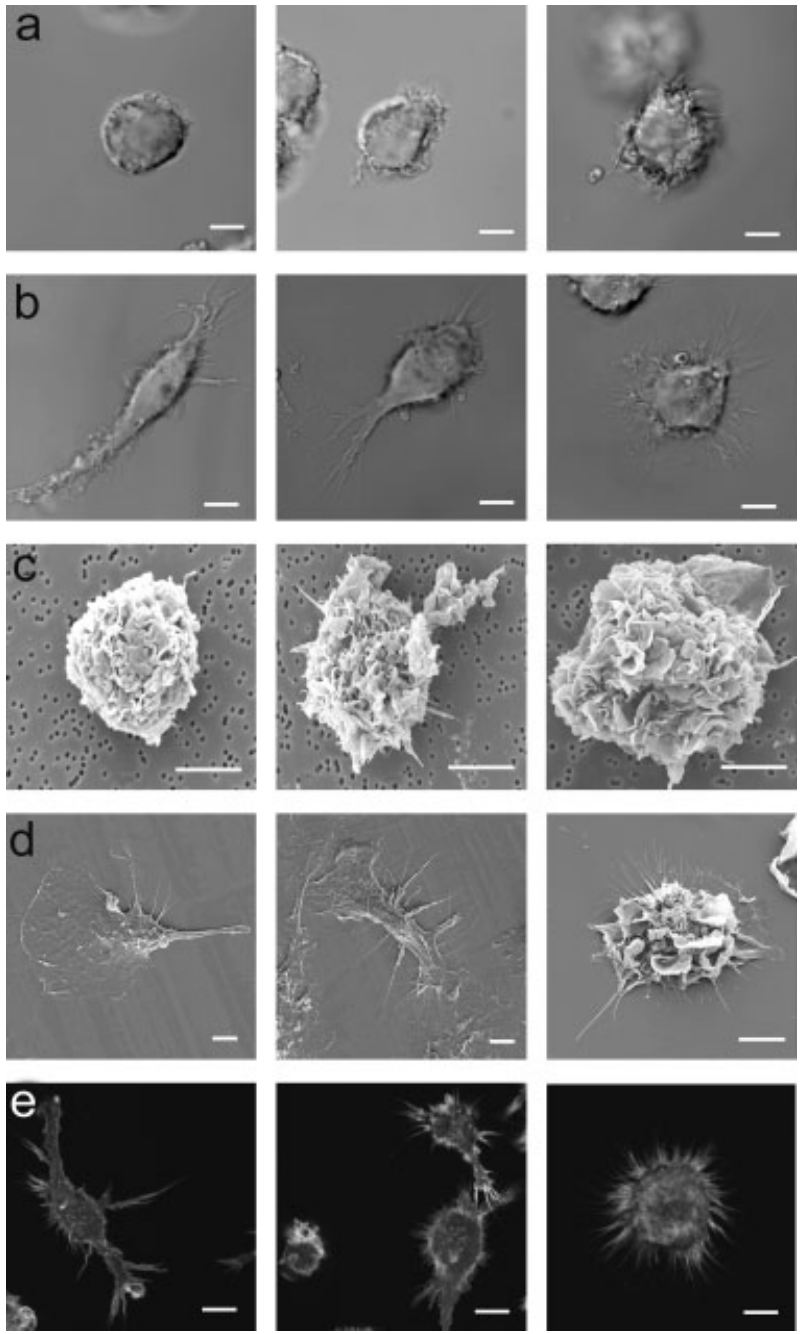

Figure 4. Cell morphology analysis by DIC, SEM and phalloidinactin staining. Representative images of nonadherent $(a, c)$ and adherent (b, $d, e$ ) cells of Medium-DCs (left column), 0-3hRP-DCs (middle column) and LPS-DCs (right column). Cells were observed using DIC light microscopy (a, b) SEM (c, d), and confocal laser-scanning microscopy for visualisation of filamentous actin after staining with TRITC-labelled phalloidin (e). Scale bars are all equal to $5 \mu \mathrm{m}$.

mature DCs with numerous cytoplasmic processes giving rise to a stellate appearance (Fig. 4b). Finally, 0-3hRP-DCs showed an intermediate morphology between the immature DCs and the pro-Th1 DCs with an elongated shape without an obvious polarity and with protruding filopodia.

SEM of both nonadherent and adherent LPS-DCs revealed the presence of numerous membrane ruffles covering the cell surface (Figs. 4c and d). Many needle-like projections were also detected on adherent LPS-DCs (Fig. 4d). In contrast, although ruffles were also detected on nonadherent Medium-DCs and 0-3hRP-DCs, they were much less pronounced than in LPS-DCs (Fig. 4c). Adherent Medium DCs did not exhibit obvious ruffles, but revealed lamellipodia reaching out over the coverslip and a retracting uropod at the rear of the cell (Fig. 4d). 0-3hRPs-DCs exhibit lamellipodia but also some hair-like projections as previously detected on adherent LPS-DCs (Fig. 4d).

Phalloidin-staining of filamentous actin on adherent cells confirmed the above observations, with LPS-DCs having a more rounded shape with an abundance of processes giving rise to a spherical stellate morphology (Fig. 4e). In contrast, Medium-DCs had a more elongated bipolar appearance with some protrusions. In comparison, $0-3 \mathrm{hRP}$-DCs had an intermediate morphology (Fig. 4e). Therefore, visual cytoskeletal changes appeared to be associated with those observed by proteomic analysis.

\section{Discussion}

Mature DCs are thought to be instrumental in guiding the developing Th cell population towards Th1 or Th2 cells [2] and while proteomic profiling of DCs has assessed differences between undifferentiated DCs and pro-Th1 DCs [2225], our study is the first to perform an in depth analysis of the proteome of Th2-inducing BM-DCs, specifically in the context of a helminth infection. We employed a gel-based proteomic approach, combining 2-DE with MALDI-MS/MS and found that whereas the overall 2-DE patterns of the three differentially matured DCs were largely similar with 93\% of spots matching between the average gels, numerous protein changes were detected. Most of the spots detected for Medium-DCs were common to 0-3hRP-DCs and LPS-DCs, but additional, unique spots were found in 0-3hRP-DCs and even more in LPS-DCs versus Medium-DCs. Therefore, our study detected fewer changes in 0-3hRP-DCs than in LPSDCs supportive of the view that pro-Th2 DCs are neither fully mature, nor immature, and instead present a 'limited maturation' phenotype.

\subsection{Cytoskeletal protein expression changes and their association with DC function}

The major changes in protein expression detected affected cytoskeletal proteins, reflecting morphological differences between the three types of differentially matured DCs observed by microscopy. Indeed, diverse microscopy techniques revealed that adherent Medium-DCs displayed an elongated bipolar morphology representative of highly migratory cells. In contrast, LPS-DCs showed the characteristics of mature DCs, with a more rounded shape, while 03hRP-DCs showed an intermediate morphology. Many cytoskeletal changes are known to be associated with the functional status of DCs, aiding cell movement during early maturation and, later ruffle formation and the loss of cellsubstratum contact $[22,23]$. Actin protein expression was decreased in 0-3hRP-DCs and LPS-DCs compared to Medium-DCs; in this respect two recent studies aid our understanding of the role of actin cytoskeleton regulation during 
the different steps of antigen presentation [22, 24]. Firstly, Watts et al. established that one of the earliest responses to TLR activation on the surface of immature DCs was a transient increase of macropinocytosis and, consequently, an increase in antigen presentation by MHC molecules [25]. This TLR-mediated actin remodelling enhanced antigen capture by DCs, by increased activity of DC membrane extensions and was coincident with a transient disassembly of actin-rich podosomes that are crucial for directional movement and transmigration [23, 25]. Thereafter, while endocytosis capacity decreases, DC cytoskeleton was remobilised in order to polarise the dendrites towards T cells and to induce an efficient activation. In our study, these dendrites were clearly revealed in the classically matured LPS-DCs. The second study showed that the regulation of DC cytoskeleton was also important in the later steps of antigen presentation to $\mathrm{T}$ cells [26]. Indeed, dendrites may have different functions including sensing of chemical signals, protrusive cell movement and consolidation of cell-cell contact [22]. Consequently, the core machinery of actin polymerisation in the cytoskeleton is involved in DC endocytosis, migration of DCs in vivo, and exploratory interactions with $\mathrm{T}$ cells to establish the immunological synapse [26, 27].

Vimentin was expressed at a high level in Medium-DCs as previously reported [28], but down-regulated in both types of mature DCs. Vimentin intermediate filaments are responsible for the regulation of cell attachment to the matrix, cell elongation and signal transduction from the plasma membrane to the nucleus. The two isoforms of gelsolin detected in our study were down-regulated in LPS-DCs versus Medium-DCs. This protein is a calcium-binding cytoskeletal protein which promotes forward extension of the lamellipodia and hence likely to be involved in polarised cell movement of immature DCs. Finally, ezrin expression is upregulated in 0-3hRP-DCs versus Medium-DCs (and also LPSDCs). It is also known to be present in ruffles and sites of formation of macropinosomes in DCs [29] and therefore, some of the antigen uptake capacities may have been retained by $0-3$ hRP-DCs.

\subsection{Changes in chaperone proteins, enzymes and other molecules}

Immature DCs are known to be specialised in antigen uptake and processing which was confirmed in our study, by the high expression of chaperone proteins and enzymes involved in protein folding. The expression of such proteins (e.g. Grp78) was similar and abundant in immature MediumDCs and pro-Th2 0-3hRP-DCs but was down-regulated in pro-Th1 LPS-DCs, as also noted by a previous study [30]. Effectively, fully matured LPS-DCs are specialised in antigen presentation to $\mathrm{T}$ cell and stimulation of immune responses, but have lost their capacity of antigen uptake and processing, confirmed by decreased expression of Grp58, Grp78, Grp94 (gp96), hsc71, calreticulin and protein disulphide isomerase precursors. Interestingly, the overexpression of protein di- sulphide isomerase in a murine monocyte/macrophage cell line strongly suppressed the LPS-induced production of inflammatory cytokines as well as NF- $\kappa$ B transcriptional activity [31]. Its down-regulation in our LPS-DCs could therefore favour their Th1-polarising function.

Our study also highlights the up-regulation of calciumbinding protein S100 A9 expression in both 0-3hRP-DCs (three isoforms) and LPS-DCs (four isoforms). This cytosolic protein is found in high amounts in patients with inflammatory diseases [32] and has been implicated in the stimulation of pro-inflammatory cytokines via the NF- $\mathrm{B}$ pathway [33]. Upon elevation of the cytosolic calcium concentration, S100 A9 translocates to plasma membranes and the cytoskeleton [32]. An analogous phenomenon is likely to happen in DCs. S100 A11 is also up-regulated. The increased expression of this pro-inflammatory cytokine [34] was greater in LPS-DCs than in 0-3hRP-DCs, compared to MediumDCs. Increased expression of peroxiredoxin 1 in LPS-DCs, and superoxide dismutase 1 in LPS-DCs and 0-3hRP-DCs was observed, concurrent with production of an enzymatic protection system against the oxidative stress conditions in which DCs frequently operate [35]. Arginase 1 was up-regulated was up-regulated in 0-3hRP-DCs versus Medium-DCs (but also versus LPS-DCs), whereas no change was revealed on the inducible nitric oxide synthase expression. These two enzymes compete together for the same substrate, L-arginine. Arginase 1 is associated with alternatively activated macrophages and with Th2-type immune responses [36, 37]. On the other hand, annexin A2, A4 and A5, which bind to calcium and charged phospholipids (plasma membrane), and have a role in membrane organisation, membrane trafficking and regulation of the calcium current across cell membrane or within cells, are down-regulated in LPS-DCs versus Medium-DCs, although only annexin A5 is also downregulated in 0-3hRP-DCs.

\subsection{Proteomics versus genomics to investigate DC phenotype}

Due to the importance of DCs in priming the acquired immune response, gene expression has been studied during precursor differentiation [30, 38, 39], classic maturation [30, 39, 40] and maturation with Th2-inducing stimuli $[6,18]$. However, several of these studies show poor concordance and/or discrepancies between mRNA transcript and protein expression changes. Effectively, there is no strict relationship between gene expression and protein production. Indeed, one of the assets of 2-DE-based proteomics studies in particular is their ability to reveal PTMs of proteins that are not apparent from genomic sequence, or mRNA expression data. These modifications are extremely important for protein function as they can determine activity, stability, localisation and turn-over. For example, several isoforms of various proteins (e.g. actin, vimentin, S100 A8 and S100 A9) were detected in our study, supporting the view that DC maturation is associated with post-transcriptional and PTMs [39]. 
However, although 2-DE has a high resolution, it fails to detect certain types of protein (e.g. hydrophobic) which do not dissolve well in the solvents used for IEF, or relatively large proteins that do not enter the second dimension gel. In addition, the absence of cytokines, or chemokines, was notable but probably reflects their secretion into the culture medium and their removal in the post-maturation wash prior to cell lysis for 2-DE separation.

\subsection{How do DCs guide Th2-type responses?}

Different hypotheses have been formulated to explain Th2 skewing by DCs. Initially, it was suggested that the absence of active DC maturation after pathogen encounter results in a defective Th1 response and, as a consequence, 'defaults' to the promotion of a Th2 response [19, 20]. On the other hand, other studies support the active maturation of pro-Th2 DCs $[6,41]$ involving specific pattern recognition receptors like TLRs [42] or C-type lectins [7]. These DCs are actively matured in the sense that they can also act to dampen the pro-inflammatory responses induced by stimuli that normally result in Th1 polarisation and inflammation $[6,7,41]$. An alternative option is that pro-Th2 DCs matured with helminth antigens exhibit an intermediate phenotype variously described as 'modulated', 'limited' or 'alternative' [10, 43]. Our proteomic analyses of pro-Th2 DCs stimulated with schistosome 0-3hRP demonstrate that they are not immature, since they have a proteome distinct to medium DCs, and therefore do not support the 'default' hypothesis for the induction of Th2 responses. We were also unable to identify a 'signature' pro-Th2 DC proteome that might be expected to result from their active maturation along a specialised pathway. However, our study clearly establishes that, in terms of their proteome, and supported by analysis of their morphology, 0-3hRP-DCs exhibit a proteome intermediate between immature Medium-DCs and pro-Th1 LPS-DCs. Although 03hRP-DCs express a number of the proteins also differentially expressed in the classically matured pro-Th1 LPS-DCs, they do not exhibit as many changes, and therefore the proteome of our pro-Th2 DCs is closer to that of immature Medium-DCs than to pro-Th1 LPS-DCs. Therefore, our proteomic study supports the view that Th2 differentiation results from the 'limited' maturation of DCs.

S. F. B. was supported by the Biotechnology and Biological Sciences Research Council (grant no. BBS/B/08531). R. S. C. (grant no. 068509) and A. P. M. (grant no. 071762 and no. 072255) were supported by the Wellcome Trust. We would like to thank Dr. Jerry R. Thomas for his assistance with mass spectrometry and his critical reading of the manuscript; we also thank Dr. Peter D. Ashton, Ann Bamford, Dr. William Castro-Borges, Peter C. Cook, Dr. Peter O'Toole, Ross A. Paveley and Dr. Martin G. Rumsby, for assistance during the course of this project.

The authors have declared no conflict of interest.

\section{References}

[1] Pulendran, B., Palucka, K., Banchereau, J., Sensing pathogens and tuning immune responses. Science 2001, 293, 253256.

[2] Shortman, K., Liu, Y. J., Mouse and human dendritic cell subtypes. Nat. Rev. Immunol. 2002, 2, 151-161.

[3] Medzhitov, R., Janeway, C. A., Jr., Innate immunity: The virtues of a nonclonal system of recognition. Cell 1997, 91, 295298.

[4] Reis e Sousa, C., Sher, A., Kaye, P., The role of dendritic cells in the induction and regulation of immunity to microbial infection. Curr. Opin. Immunol. 1999, 11, 392-399.

[5] MacDonald, A. S., Straw, A. D., Bauman, B., Pearce, E. J., CD8-dendritic cell activation status plays an integral role in influencing Th2 response development. J. Immunol. 2001, 167, 1982-1988.

[6] Balic, A., Harcus, Y., Holland, M. J., Maizels, R. M., Selective maturation of dendritic cells by Nippostrongylus brasiliensis-secreted proteins drives Th2 immune responses. Eur. J. Immunol. 2004, 34, 3047-3059.

[7] Cervi, L., MacDonald, A. S., Kane, C., Dzierszinski, F., Pearce, E. J., Cutting edge: Dendritic cells copulsed with microbial and helminth antigens undergo modified maturation, segregate the antigens to distinct intracellular compartments, and concurrently induce microbe-specific Th1 and helminthspecific Th2 responses. J. Immunol. 2004, 172, 2016-2020.

[8] Thomas, P. G., Harn, D. A., Jr., Immune biasing by helminth glycans. Cell. Microbiol. 2004, 6, 13-22.

[9] Jenkins, S. J., Mountford, A. P., Dendritic cells activated with products released by schistosome larvae drive Th2-type immune responses, which can be inhibited by manipulation of CD40 costimulation. Infect. Immun. 2005, 73, 395-402.

[10] Perona-Wright, G., Jenkins, S. J., MacDonald, A. S., Dendritic cell activation and function in response to Schistosoma mansoni. Int. J. Parasitol. 2006, 36, 711-721.

[11] Curwen, R. S., Ashton, P. D., Sundaralingam, S., Wilson, R. A., Identification of novel proteases and immunomodulators in the secretions of schistosome cercariae that facilitate host entry. Mol. Cell. Proteomics 2006, 5, 835-844.

[12] Hogg, K. G., Kumkate, S., Mountford, A. P., IL-10 regulates early IL-12-mediated immune responses induced by the radiation-attenuated schistosome vaccine. Int. Immunol. $2003,15,1451-1459$.

[13] Hogg, K. G., Kumkate, S., Anderson, S., Mountford, A. P., Interleukin-12 p40 secretion by cutaneous CD11c+ and F4/ $80+$ cells is a major feature of the innate immune response in mice that develop Th1-mediated protective immunity to Schistosoma mansoni. Infect. Immun. 2003, 71, 3563-3571.

[14] Mountford, A. P., Trottein, F., Schistosomes in the skin: A balance between immune priming and regulation. Trends Parasitol. 2004, 20, 221-226.

[15] Kumkate, S., Jenkins, G. R., Paveley, R. A., Hogg, K. G., Mountford, A. P., CD207(+) Langerhans cells constitute a minor population of skin-derived antigen-presenting cells in the draining lymph node following exposure to Schistosoma mansoni. Int. J. Parasitol. 2007, 37, 209-220.

[16] Jenkins, S. J., Hewitson, J. P., Jenkins, G. R., Mountford, A. P., Modulation of the host's immune response by schistosome larvae. Parasite Immunol. 2005, 27, 385-393. 
[17] Jenkins, S. J., Hewitson, J. P., Ferret-Bernard, S., Mountford, A. P., Schistosome larvae stimulate macrophage cytokine production through TLR4-dependent and -independent pathways. Int. Immunol. 2005, 17, 1409-1418.

[18] Kane, C. M., Cervi, L., Sun, J., McKee, A. S. et al., Helminth antigens modulate TLR-initiated dendritic cell activation. $J$. Immunol. 2004, 173, 7454-7461.

[19] Moser, M., Murphy, K. M., Dendritic cell regulation of TH1TH2 development. Nat. Immunol. 2000, 1, 199-205.

[20] Kelsall, B. L., Biron, C. A., Sharma, O., Kaye, P. M., Dendritic cells at the host-pathogen interface. Nat. Immunol. 2002, 3, 699-702.

[21] Curwen, R. S., Ashton, P. D., Johnston, D. A., Wilson, R. A., The Schistosoma mansoni soluble proteome: A comparison across four life-cycle stages. Mol. Biochem. Parasitol. 2004, 138, 57-66.

[22] Burns, S., Thrasher, A. J., Dendritic cells: The bare bones of immunity. Curr. Biol. 2004, 14, R965-R967.

[23] Watts, C., Zaru, R., Prescott, A. R., Wallin, R. P., West, M. A., Proximal effects of Toll-like receptor activation in dendritic cells. Curr. Opin. Immunol. 2007, 19, 73-78.

[24] Benvenuti, F., Hugues, S., Amigorena, S., Dendritic cell cytoskeleton mobilization to enhance antigen presentation. Med. Sci. (Paris) 2005, 21, 13-15.

[25] West, M. A., Wallin, R. P., Matthews, S. P., Svensson, H. G. et al., Enhanced dendritic cell antigen capture via toll-like receptor-induced actin remodeling. Science 2004, 305, 11531157.

[26] Benvenuti, F., Hugues, S., Walmsley, M., Ruf, S. et al., Requirement of Rac1 and Rac2 expression by mature dendritic cells for T cell priming. Science 2004, 305, 1150-1153.

[27] West, M. A., Prescott, A. R., Eskelinen, E. L., Ridley, A. J., Watts, C., Rac is required for constitutive macropinocytosis by dendritic cells but does not control its downregulation. Curr. Biol. 2000, 10, 839-848.

[28] Pereira, S. R., Faca, V. M., Gomes, G. G., Chammas, R. et al., Changes in the proteomic profile during differentiation and maturation of human monocyte-derived dendritic cells stimulated with granulocyte macrophage colony stimulating factor/interleukin-4 and lipopolysaccharide. Proteomics 2005, 5, 1186-1198.

[29] Erwig, L. P., McPhilips, K. A., Wynes, M. W., Ivetic, A. et al., Differential regulation of phagosome maturation in macrophages and dendritic cells mediated by Rho GTPases and ezrin-radixin-moesin (ERM) proteins. Proc. Natl. Acad. Sci. USA 2006, 103, 12825-12830.

[30] Le Naour, F., Hohenkirk, L., Grolleau, A., Misek, D. E. et al., Profiling changes in gene expression during differentiation and maturation of monocyte-derived dendritic cells using both oligonucleotide microarrays and proteomics. J. Biol. Chem. 2001, 276, 17920-17931.

[31] Higuchi, T., Watanabe, Y., Waga, I., Protein disulfide isomerase suppresses the transcriptional activity of NF-kappaB. Biochem. Biophys. Res. Commun. 2004, 318, 46-52.
[32] Donato, R., S100: A multigenic family of calcium-modulated proteins of the EF-hand type with intracellular and extracellular functional roles. Int. J. Biochem. Cell Biol. 2001, 33, 637-668.

[33] Sunahori, K., Yamamura, M., Yamana, J., Takasugi, K. et al., The S100A8/A9 heterodimer amplifies proinflammatory cytokine production by macrophages via activation of nuclear factor kappa B and p38 mitogen-activated protein kinase in rheumatoid arthritis. Arthritis Res. Ther. 2006, 8, R69.

[34] van Horssen, R., Eggermont, A. M., ten Hagen, T. L., Endothelial monocyte-activating polypeptide-II and its functions in (patho)physiological processes. Cytokine Growth Factor Rev. 2006, 17, 339-348.

[35] Rivollier, A., Perrin-Cocon, L., Luche, S., Diemer, H. et al., High expression of antioxidant proteins in dendritic cells: Possible implications in atherosclerosis. Mol. Cell. Proteomics 2006, 5, 726-736.

[36] Loke, P., Nair, M. G., Parkinson, J., Guiliano, D. et al., IL-4 dependent alternatively-activated macrophages have a distinctive in vivo gene expression phenotype. BMC Immunol. 2002, 3, 7 .

[37] Nair, M. G., Cochrane, D. W., Allen, J. E., Macrophages in chronic type 2 inflammation have a novel phenotype characterized by the abundant expression of $\mathrm{Ym} 1$ and Fizz1 that can be partly replicated in vitro. Immunol. Lett. 2003, 85, 173-180.

[38] Lapteva, N., Ando, Y., Nieda, M., Hohjoh, H. et al., Profiling of genes expressed in human monocytes and monocytederived dendritic cells using cDNA expression array. Br. J. Haematol. 2001, 114, 191-197.

[39] Richards, J., Le Naour, F., Hanash, S., Beretta, L., Integrated genomic and proteomic analysis of signaling pathways in dendritic cell differentiation and maturation. Ann. N. Y. Acad. Sci. 2002, 975, 91-100.

[40] Hashimoto, S. I., Suzuki, T., Nagai, S., Yamashita, T. et al., Identification of genes specifically expressed in human activated and mature dendritic cells through serial analysis of gene expression. Blood 2000, 96, 2206-2214.

[41] Goodridge, H. S., Marshall, F. A., Wilson, E. H., Houston, K. M. et al., In vivo exposure of murine dendritic cell and macrophage bone marrow progenitors to the phosphorylcholine-containing filarial nematode glycoprotein ES-62 polarizes their differentiation to an anti-inflammatory phenotype. Immunology 2004, 113, 491-498.

[42] Agrawal, S., Agrawal, A., Doughty, B., Gerwitz, A. et al., Cutting edge: Different Toll-like receptor agonists instruct dendritic cells to induce distinct Th responses via differential modulation of extracellular signal-regulated kinase-mitogen-activated protein kinase and c-Fos. J. Immunol. 2003, 171, 4984-4989.

[43] Pearce, E. J., Kane, C. M., Sun, J., Taylor, J. et al., Th2 response polarization during infection with the helminth parasite Schistosoma mansoni. Immunol. Rev. 2004, 201, 117-126. 